\title{
Recreational Sports Coaching of North Sumatera
}

\author{
Melfa Br Nababan ${ }^{1}$ \\ Graduate Student of Sport Education \\ State University of Medan \\ North Sumatra, Indonesia \\ Email: nababanmelfa@yahoo.com \\ Rahma Dewi ${ }^{2}$ \\ Graduate Lecturer of Sport Education \\ State University of Medan \\ North Sumatra, Indonesia \\ Imran Akhmad ${ }^{3}$ \\ Graduate Lecturer of Sport Education \\ State University of Medan \\ North Sumatra, Indonesia
}

\begin{abstract}
Recreational sports is a physical activity done in leisure time to bring joy, recovery of physical and mental strength and preserve and enhance the cultural richness of the region so that through recreational sports can improve physical fitness, prioritize the values of pleasure or satisfaction, positive, healthy, without coercion. Exercising is the basic right of every human being regardless of race, religion, social class, and gender is called sport for all. Community activity and interest in sport recreation is increasing because recreation sport is carried out community based on cheap, easy, interesting, benefit, and missal principle. Therefore, it is necessary to promote recreational sports as an effort to cultivate and activate sports associations in the community, and to organize a tiered and sustainable recreational sports festival at the regional, national and international levels. FORMI is the parent organization of the sport to be a gathering place of the sport recreation organization that grows and develops in the community can foster the sports branches of recreation owned by the community in order to cultivate the community and socialize the sport. The development of recreational sports aims to explore, develop, preserve and utilize traditional recreational sport that grows and develops as a culture in society. Through recreational sports coaching can contribute to the improvement of cultural and sport recreational achievements at national and international level.
\end{abstract}

Keywords: Coaching, Sports Recreational

\section{INTRODUCTION}

Exercising is the basic right of everyone regardless of race, religion, social class, or gender. Therefore the International Sports Committee (IOC) of 1983 has been promoting a sports program for the whole society called Sport for All. This program has the goal of encouraging the realization of a condition where sports activities can be carried out by every level of society, regardless of age limit, gender differences, or different socioeconomic conditions. Through sports programs for the community will further disseminate the health and social benefits that can be gained by all members of the community through regular physical activity (http://www.olympic.org/sport-for-all-commission) [1].

In Indonesia, stipulated in Law no. 3 of 2005 on the National Sports System (SKN) is enacted, there is a change of title which was originally known as "sports community" to "recreational sport". It is contained in article 17 that divides the scope of sports into three activities, namely sports education, recreational sports, and sports achievement. Sports recreation is a sport performed to fill the spare time with the ultimate goal according to RI Law no. 3/2005 on the National Sports System (SKN) is, "to gain physical health, fitness, joy, joy, develop social relationships, and preserve and enhance the nature of regional and national culture".

The scope of recreational sports (sports community) in the National Sports System Act (SKN) is described in Article 19, as follows: Sports recreation is performed as part of (1) the process of restoring health and fitness. (2) recreational sports may be exercised by any person, educational unit, institution, association or sport organization. (3) recreational sport as referred to in paragraph (1) aims to: a) acquire health, physical fitness, and joy. b) building social relationships, preserving and enhancing regional and national cultural wealth. (4) the government and society are obliged to explore, develop and promote recreational sports. (5) any person hosting a particular recreational sport containing risks to environmental sustainability, maintenance of facilities, and safety, and health shall: a) comply with the provisions and procedures established in accordance with the type of sport. b) provide instructors or guides with knowledge and skills 
appropriate to the type of sport. (6) recreational sport as referred to in paragraph (5) must meet the requirements set by sports associations or organizations [2].

\section{Coaching}

\section{DISCUSSION}

Sports coaching is a pattern as "basic guidance and is the basis for the preparation of programs of Sport Development Indonesia which takes place in an integrated and sustainable". Implementation of the archetype of sports development is set forth in the form of policies and actions of the government, community, and family, both short-term, medium-term and long-term programs taking into account the applicable regulations. The wisdom of setting the basic pattern of sports coaching in Indonesia is to provide guidance and direction in order to improve the national sport movement with the aim, to the family and society as a whole and sustainable and efficient and effective, so that gradually can realize the ideals of the Indonesian nation, such as as defined in the 1945 Constitution.

In the long-term sports coaching system, the initial stage begins with the exercise of sport throughout the community with the slogan that has been proclaimed the government is "To promote sports and to exercise the community". In the International circles known as "Sport For All". After the sport becomes bulk, then many emerging talented seeds. Through various scientific approaches, talented seeds are selected for each sport, which are then guided to achieve the highest achievement (TAPiS Jurnal, Vol. 16 No. 02 July-Desember 2016) [3].

In GBHN 1993 it has been stated explicitly that the fostering and development of sport which is part of the effort to improve the quality of Indonesian human being, is aimed at improving the physical, mental and spiritual freshness of society, and is aimed at the formation of character and personality, discipline and high sportsmanship and improvement of achievement can evoke a sense of national pride. In the fostering of sports achievement, it is necessary to continue the training of athlete as early as possible through search and scouting of talent, breeding, education and training of sport based on science and technology more effectively and efficiently and improving the quality of sports organization both central and regional level (GBHN, 1993 : 143-144) [4].

Guidance is the fostering, renewing or process of deeds, ways of fostering, effort, action, and activities carried out in a useful and effective manner to obtain better results (KBBI) [5]. According to Lutan Rusli et al (2000: 11) coaching is as an effort to organize or how to achieve a goal [6]. In general, coaching takes place through the process of releasing inhibiting things, and learning knowledge with new skills that can improve the standard of living and work better. The guidance concerns the planning, organizing, financing, coordination, implementation, and supervision of a job to achieve a maximum goal. Coaching is an effort or action taken to change a situation well to get the goal to be achieved optimally (Kusnanik, 2013: 129) [7].
In Indonesian General Dictionary (2003: 160)) explains that coaching is development or renewal [8]. Coaching activities carried out namely the development and refinement and the discovery of new things. According to Ruslan (2011: 49) coaching means effort, or action and activities performed in a useful and effective way to obtain better results [9]. In the effort of fostering these achievements, there must be intrinsic and extrinsic elements (support) needed. Elements such as trainers, administrators, infrastructure, training programs, and so forth. In addition, other things that are not less important is the funding is a factor for the implementation of a coaching in the organization. According to Herman Subarjah (2000: 68) factors to be considered in the preparation of sports performance improvement programs, among others: (1) clear coaching purposes, (2) systematic training programs, (3) appropriate training materials and methods and evaluation can measure the success of the coaching process, (4) the athlete's characteristics being nurtured either physically or psychologically, (5) the ability of the trainer, (6) the facilities and infrastructure or facilities, (7) the condition of the coaching environment. (Journal of Sports Health Vol. 06 No. 2 October 2016 edition pp 426-432) [10].

Thus it can be concluded that coaching is a business and activities undertaken in order to achieve change with a hard effort for better results through planning, organizing, financing, coordination, implementation and monitoring and evaluation activities used as measuring the success of the coaching process.

\section{1) Planning}

According to Subeki Ridhotullah (2015: 125) planning is thinking about what to do with the resources it has [11]. The way in which a plan is made is to say that planning means seeking and finding answers to the following six questions $(5 \mathrm{~W}+1 \mathrm{H})$ : what, why, who, when, where, and how. What to do, what funding sources and resources are needed, and what infrastructure is needed. Why, trying to find convincing justification about the answers given to other questions in the planning process. Who, no one will deny that whether the plan can be implemented or not, ultimately depends on who will implement the plan. When, that is not to act is often as important as knowing when is the right time to do something. Where, the effort to find and find answers to the question where to then be decided, related to the use of the location where various activities will take place. How, in a plan is clearly seen the answer to the question of how the people and various units of work within the organization carry out the tasks it is responsible for solving them (Siagian Sondang, 2004: 37) [12].

\section{2) Organizing}

Organizing can be defined as determining the work to be done, grouping tasks and handing out work to each board, part placement and determining relationships. Organization is defined as describing patterns, schemes, charts showing command lines, management positions, and 
relationships, Malayu Hasibuan (2006: 18) [13]. Organizing function (organizing $=$ division of labor) is closely related to the function of planning because the organization must be planned. organizing is a management function and is a dynamic process, while the organization is a tool or a container that static.

\section{3) Financing}

According to Malayu Hasibuan (2006: 101) financing is an endeavor of the expected results and expenditures provided to achieve the results stated in the unity of money. So the budget describes the receipts and expenditures made on each field. In this budget, it should be noted that the costs and results obtained in the National Sports System Act in article 70 indicate that the source of sports funding can be obtained from: (a) the community through activities under applicable provisions, (b) mutually beneficial cooperation, c) non-binding foreign assistance, (d) results of sports industry enterprises, (e) other legal sources under the provisions of legislation.

\section{4) Coordination}

Is a matter of organizing an organization or activity so that the rules and actions that will be carried out are not conflicting or confusing. The division of work tasks and parts, the smallest units within an organization tends to arise the power of separation from the overall organizational goals. In order to prevent such a thing there must be an attempt to restore the separating movement through coordination activities. Coordination is an element to direct the activities of all unut-unit organizations to focus on making the most possible contribution to achieve the overall organizational goals

\section{5) Implementation}

Is an action or execution of a well-crafted and detailed plan, the implementation is usually done after the planning is considered to be ready. In simple terms implementation can be interpreted application. Implementation according to Big Indonesian Dictionary is process, way, action executing (design, decision, and so on).

\section{6) Supervision}

Supervision / controlling is a process to determine what work has been done, assess it and, if necessary, correct it with the intent that the work is carried out in accordance with the original plan (Manullang, 2002: 173) [14]. Precautionary supervision is to obtain an effective supervisory system, it is necessary to meet some supervisory principles. Two basic principles which constitute an effective oversight system are the existence of specific plans and the giving of instructions and authority to subordinates. The first principal principle is the standard or measuring tool rather than the work performed by the subordinates. The plan is a pointer to a successful implementation of the work or not.

Nevertheless, the second key principle is a necessity that needs to be in place so that the oversight system is actually effectively implemented. Clear authority and instructions should be given to subordinates because that is why it is known whether the subordinate has performed his duties properly. On the basis of instructions given to subordinates can be supervised the work of a subordinate.

\section{7) Evaluation}

Suharsimi Arikunto (2004: 3) suggests that evaluation is an activity to collect information about the workings of something, which then the information is used to determine the right alternative in making decisions. The main function of this evaluation is to provide informationinformation useful to the decision maker to determine the policy to be adopted based on the evaluations made [15].

\section{Sports Recreation}

Sports is a systematic process of all activities or endeavors that can encourage the development and fostering of the physical and spiritual potential of a person as an individual or member of society in the form of games, competitions / matches and peak performance in the context of the establishment of a qualified Indonesian man based on Pancasila. While recreation is derived from the Latin recreation of re-creare which literally means "throwing back", is an activity done to refresh one's body and spiritual. This is an activity someone does besides the job. In Big Indonesian Dictionary, recreation is a refreshing of body and mind, something exciting and refreshing like entertainment and picnic.

Sport and recreation are closely related, but if the word sport and recreation are linked it will have its own meaning, therefore regarding the notion of recreational sport (sports community). Haryono (1978: 10) also says that recreational sports are physical activities performed at leisure on the basis of desire or desire arising from the satisfaction and pleasure [16]. In performing these sports activities the principal prioritizes the values of pleasure or satisfaction, positive, healthy, without coercion, and done in the context of leisure time.

Furthermore, according to Herbert Haag (1994) cited by Nurlan Kusmaedi (2002: 4) said that, "recreational spotr / leisure time sport are forms of physical activity in leasure under a time perspective. It comprises sport after work, on weekends, in vacations, in retirement, or during periods of (unfortunate) unemployment". Sports recreation / sporting tours are sport activities that are shown for recreation or leisure, as well as sports education ie sports for educational purposes, or health sports ie sports for health purposes as well as sports achievements ie sports for achievement purposes. Sports tours are sports that are done while traveling or visiting.

From some definitions of recreational sports the authors draw conclusions about the keywords from the definition of recreational sports ie, physical activity done in leisure time to fill the leisure time that brings pleasure and fun so that through recreational sports can improve physical fitness and give priority to the values of pleasure or satisfaction, positive, healthy, without coercion.

Sports recreation is basically done to fill the spare time. The main purpose of recreational sports is to rest refreshing (relaxation) and also allows for social contact. According to Suryadi Damanik (2014: 11) recreational sport 
is an activity in which contained elements or values of sports activities performed at a certain place in order to get a satisfaction of its own, without any sense of burden [17]. Sports recreation is a sport done by people with a passion and ability that grows and develops in accordance with the local cultural conditions and values for health, fitness and joy. Leisure sports are done in leisure time or leisure time.

From the opinion of experts, recreational sports are a sport that is done in spare time to refresh attitude and mental so as to restore physical and mental strength, recreational sports activities conducted based on pleasure, satisfaction and joy.

Specifically the role of recreational sport in social life can be classified as follows: (1) develop a sense of appreciation and love for the environment and preserve it. (2) develop understanding and capability and understanding of the importance of maintaining environmental balance and using it wisely. (3) awaken human consciousness about the importance of fostering mutual relationship between human and environment and to be more familiar with the nature or character. (4) help develop positively the behavior and social relationships to the individual. (5) help develop science about healthy environmental practices. (6) opens the opportunity to build inter-community cooperation with recreation service organizations in particular and society in general. (7) foster and strengthen self-confidence and selfesteem which is a strong foundation for fostering "self concept". (8) strengthen the fraternity and the growth of mutual support among group members. (9) adding or improving skills and coordination. Adding personal pleasure and a sense of togetherness between group members. (10) educate a person to be able to fill his spare time with positive activities in the sense of not harming himself, others, the environment and otherwise preventing the emergence of negative activities such as drug use, destructive activity vandalism, and other similar negative activities. (11) develop a healthy life culture, both for individuals and for others and for their natural environment.

\section{CONCLUSION}

The development of recreational sports aims to explore, develop, preserve and utilize traditional recreational sport that grows and develops as a culture in society. Through recreational sports coaching can contribute to the improvement of cultural and sport recreational achievements at national and international levels.

\section{Reference}

[1] Sport For All, http://www.olympic.org/ sport-for-all-commission, diunduh tanggal 26 Juni 2012.

[2] Undang-undang Republik Indonesia Nomor 3 Tahun 2005 Tentang Sistem Keolahragaan Nasional, Jakarta: Biro Humas dan Hukum Kementrian Negara Pemuda dan Olahraga republik Indonesia, 2007.

[3] Jurnal TAPiS, Vol. 16 No. 02 Juli-Desember 2016

[4] Dikjen Dikti Depdikbud (1994) UUD 1945, P-4, GBHN, Tap-tap MPR1993, Pidato Pertanggung-Jawaban Presiden Mandataris, bahan Penataran dan bahan referensi Penataran. Jakarta. Ditjen Dikti.

[5] Kamus Besar Bahasa Indonesia (KBBI). (Online), (http://kbbi.web.id/bina,diakses pada 23 Januari 2016. Kamus Besar Bahasa Indonesia (KBBI), (Online),(http://kamusbesarbahasaindonesia.org./analisis, diakses pada 2 Maret 2016)

[6] Lutan, Rusli. dkk. 2000. Dasar-Dasar Kepelatihan. Departemen Pendidikan Nasional Direktorat Jenderal Pendidikan Dasar Dan Menengah Bagian Proyek Penataran Guru SLTP Setara D-III Tahun 2000 .

[7] Kusnanik, Nining Widyah. 2013. "Evaluasi Manajemen Pembinaan Prestasi PRIMA Pratama Cabang Olahraga Panahan di Surabaya". Jurnal IPTEK Olahraga. Vol. 15 (2): hal. 125-137.

[8] Kamus Umum Bahasa Indonesia (KUBI). (Online) https://books.google.co.id/books.

[9] Ruslan. 2011. "Meningkatkan Kondisi Fisik Atlet Pusat Pendidikan Dan Latihan Olahraga Pelajar (PPLP) Di Provinsi Kalimantan Timur". Jurnal ILARA.(Online)Vol.2:hal.4556.(http://digilib.unm.ac.id/files/disk1 17/universitas\%20negeri\%20 maka sar-digilib-unm-ruslan-348-17.rusla-c.pdf, diunduh pada 22 Februari 2016)

[10] Linda Agnes Maulida R.2016. "Pembinaan Prestasi Bola Voli Klub Ivolta Kecamatan Saronggi Kabupaten Sumenep”.Jurnal Kesehatan Olahraga Vol. 06 No 2 edisi Oktober 2016 hal 426432).

[11] Ridhotullah, Subeki and Mohammad Jauhar.2015. Pengantar Manajemen. Jakarta: Prestasi Pustaka Jakarta.

[12] Siagian, Sondang P.2004. Manajemen Sumber Daya Manusia. Jakarta: Bumi Aksara.

[13] Hasibuan, Malayu S. P.2002. Manajemen Sumber Daya Manusia.Jakarta: Bumi Aksara.

[14] Manulang, M.2001. Dasar-Dasar Manajemen. Yogyakarta:Gajah Mada University Press.

[15] Suharsimi Arikunto.2004.Dasar-Dasar Evaluasi Pendidikan.Jakarta:Bumi Aksara

[16] Haryono.1978.(Online)http://file.upi.edu/ Direktori/FPOK/JUR._PEND._OLAHRAGA/197603082005011S UHERMAN_SLAMET/modul_bermain_08/bab_6_teori_bermain. pdf.

[17] Suryadi Damanik.2014. Olahraga Rekreasi Prinsip dan Aplikasi. Medan:Unimed Press. 